\title{
Importance and value of Artificial Intelligence in Financial Sector - A critical Review
}

\author{
Dr. Vivek Joshi ${ }^{1} \mid$ Dr. Prafulla Ranjan ${ }^{2}$ \\ ${ }^{1}$ Director, Creative Heads Consultants, Jaipur, Rajasthan, India. \\ ${ }^{2}$ Dean, IIMT College of Engineering, Greater Noida, India.
}

To Cite this Article

Vivek Joshi \& Prafulla Ranjan. Importance and value of Artificial Intelligence in Financial Sector - A critical Review. International Journal for Modern Trends in Science and Technology 7, 6-11 (2021).

Article Info

Received on 27-March-2021, Revised on 20-April-2021, Accepted on 24-April-2021, Published on 29-April-2021.

\section{ABSTRACT}

Artificial Intelligence has brought a great transformation to the financial sector by providing various opportunities for tailor made and customized services, reduction in costs and developing new models of business. Additionally, Artificial Intelligence has really boomed in past few years and many companies in different sectors have adopted it and applied in their operations. Many times, Artificial Intelligence is called as automation of the process within the sector, but a better way of usage of technology for the betterment of sector, mainly financial sector. Huge changes have been brought in financial sector through technology of artificial intelligence that created a range of innovative financial services such as intelligent consultant, intelligent lending, monitoring, and warning, as well as intelligent customer service. A sample of 175 respondents in which 62.29\% "male" and $37.71 \%$ "female" has been considered by a "standard questionnaire" created on five-point interval scale.

KEYWORDS: Artificial intelligence, business, finance, machine learning, technology, Banking Industry, AI Applications

\section{INTRODUCTION}

There are two basic ideas that are involved in artificial intelligence; the first is artificial intelligence study the thought process of humans and second is, it represents such process through machines like robots and computers. There are different innovative ways in which financial institutes are applying artificial intelligence. One of the research says that by around year 2035, every sector of the economy will adopt artificial intelligence and its productivity will be boomed. It cannot be denied that extreme transformation has been brought by artificial intelligence in financial sector. For each work, people are now switching towards fully automated system. Artificial intelligence has assisted financial sector by providing different services in an automated way such as smart wallet, personalized banking services, voice assisted banking, underwriting, Data-driven AI applications for lending purposes, customer support etc. (Patel, 2018). Another important innovation of Artificial intelligence is Chatbot, it is a software that can set up a conversation with user in natural language by messaging application, websites, mobile application etc. It is a technological innovation of artificial intelligence; it assists customers with reference to distinct options of investment. As compared to traditional human advisors, chatbot advisors are much better advisors when compared for elements such as convenience and price, low fees and access to it 24/7. It is about effectiveness and accountability for which human advisory services are preferred. Based on the information given by the customers or investors, decision is taken by the advisors of Chatbot and cannot 
encourage investors to concentrate on their financial aims. For the management of big portfolio Chatbot advisors are not effective, they are also not suitable in complicated financial conditions. Chatbot advisors are designed in such a manner that it can cater to large number of customers that too in accost effective way and also resolve the nonsense and wrong decisions taken by humans. Operational cost of Chatbot is very low and it can handle large number of accounts as compared to traditional financial advisor. Chatbot is the best option for those investors who cannot afford to hire a financial advisor because of their high fees. Chatbot must be designed in such a way that it becomes easy and understandable to adopt (Patil and Kulkarni, 2019).

Artificial Intelligence is becoming popular every day as banks and other financial institutions have started adopting it and implementing this new technology and changing the way they were dealing with their customers. Thus, it cannot be denied that the future of artificial intelligence is very bright in the banking and financial sector and for the customers as well it has become very easy to carry on their transactions at any time and from any place and without waiting and standing in long queues of banks. The main goal of artificial intelligence is to provide customized and personalized high quality satisfaction to their customers, which is efficient, time, and cost saving. Traditional banks who are competing with the tech-savvy fin-tech players have started adopting latest technologies such as Artificial Intelligence. Artificial Intelligence empowers banks and transforms their way of operation, develop innovative products and services, and influence the experiences of customers. To survive in this competitive market, banks must grasp artificial intelligence and adopt their strategy of doing a business (Kumar, Aishwaryalakshmi, and Akalya, 2020). Artificial Intelligence is a new field of challenges as well as opportunities, it an inescapable result of the development of technology and science. However, at the same time, it also has some challenges in its application. Hence, the financial industry must understand the artificial intelligence and make its application ultimate in their field of finance. There are some important guidelines for the designing of artificial intelligence, first guideline is, the aim to guide complete process of development of artificial intelligence, its usage, its design, management as well as control, its careful promotion and application $\mathrm{n}$ risk management in financial sector. The use of artificial intelligence in the field of financial risk management, for collection of information it must follow certain method to make sure the validity of information collection and interest of the customer in not harmed in any manner. The strength and type of artificial intelligence information collection and behavior of information is regulated (Xie, 2019).

\section{LITERATURE REVIEW}

Meghani (2020) studied that the future of banking is in the hands of artificial intelligence as it carries the strength of advanced data analytics to deal with financial frauds, illegal transactions and in order to improve compliance. A revolutionary idea was developed in financial market in the form of Bit-coin in the year 2009. Bit-coin was considered as the digital money of new era. Bit-coins are secured and non-centralized and it provides honest and non-inflatable money to customers. In this work, the author has also examined the technology of artificial intelligence and block chain as well as how they can contribute in Indian banking industry.

Vedapradha and Ravi (2018) concluded that banks of todays' market are automating their processes, migration of their infrastructure as well as application to cloud in order to create flawless journey of their customers. Even after the increase application of artificial intelligence in the banking industry and its contribution towards innovation of banking sector, adoption of $\mathrm{AI}$ is still in the beginning stage. Some banks are still hesitating from adopting this technology due to some of its common threats such as technical complications, low level of maturity, its infrastructure, reduction in work force, less transparency etc.

Vijay (2019) found that there are various advantages that are been provided to banking industry by artificial intelligence. Business processes of banks have been transformed by artificial intelligence as well as the customer services. Artificial intelligence also helps in the detection of financial frauds, meeting regulatory compliance and evaluates creditworthiness of an individual. Application of artificial intelligence holds the capacity to develop more effective business processes; it offers personalized services and helps if larger aims like financial inclusion. It is a fact that latest push towards digitalization is extremely influencing the traditional models of banking. However, it has also uncovered the institutions towards threats of cyber security and liabilities.

Jewandah (2018) revealed that after demonetization, in banking sector along with all other sector is experiencing a digital boom. The traditional system of banking is being developed 
and has started adopting new and latest technologies such as artificial intelligence, clock chain, cloud etc. as it cuts down the operational costs as well as improves business efficiency. Although artificial intelligence is still in developing stage and banks are still at the crucial stage of the revolution of artificial intelligence. The production costs of the business will be reduced by the development and improvement in the industry of artificial intelligence. Management of various industries must upgrade their systems and adopt latest technologies to make their work easy and up to date.

Mhlanga (2020) explained that now a day the central point of debates and discussion is financial inclusion and about how to make sure how to make people financially active who are still at low levels of pyramid. Alternatively, fin-tech companies are taking benefits of the accessibility of artificial intelligence and applying it to make sure that the aim of digital financial inclusion is fulfilled by including low income group of people, poor individuals, young individuals, women, small business enterprises in financial market. It is found in the study that there is strong influence of artificial intelligence on the digital financial inclusion in areas such as investigation of risk, measurement, and management, tackling the issues of imbalance of information, utilizing customer support and helpdesk through chatbot and discovery of frauds and cyber safety.

Kumar et. al. (2019) studied that artificial intelligence helps in the betterment of customer satisfaction, reduces frauds and increase profits, it also reduces operational costs and complications. Proof of the concept has utilized cases of corporates related to artificial intelligence resulting in extreme development in the industry of insurance. Artificial intelligence helps in customizing and personalizing the services that are provided to customers, it also useful in advertising as well as marketing campaigns. Hence, insurers can assimilate new sources of data and proprietary data from digital as well as social media from sensory devices. Thus, customized experiences can be made by evaluating segments of customers for personalization.

Burri et. al. (2019) concluded that modern and latest technologies are entering into the market and making their ways in almost every field if business. In this sense, the insurance sector does not lack behind others. The history of application of statistics in insurance sector is quite long. Hence, the truth that insurance companies are diligently utilizing analytics of data science is not astonishing. Purpose of applying analytics of data science in insurance sector is similar just like in any other industry - for the betterment of marketing strategies, improvement of business, enhancement of income and reduces the cost. In this work, several techniques of machine learning is presented to analyze claims of insurance effectively and comparing their performance by making use of different metrics.

Alzaidi (2018) revealed that from this work, the technological adaptation by banking sector in Middle east have dragged at slower pace in comparison to other global markets. Eventually, there has been a shift in attitude with reference to tools of technology and now the professionals of banking industry are aiming to work hand in hand with the development of technology. The adaptation of artificial intelligence is far from reaching to complete the level of maturity within the industry but usage of artificial intelligence in banking sector has become trendy. Hence, it is understood that, the performance of banking sector in Middle East has boosted after the application of artificial intelligence.

Lakshminarayana and Deepthi (2019) found that the boom of technology has positively influenced almost every industry mainly the banking industry, especially after demonetization. The advancement have been noticed in customary banking and the ever increasing number of banks are incorporating new up gradation such as Cloud, artificial intelligence, square chain to reduce their costs of operation and improve their efficiency. It is the fact that artificial intelligence is still in its early stage and banks are at the edge of manmade apprehension alteration. Efficiency of the business will be increased at the lowest cost by the improvement and advancement in artificial intelligence business. There is no doubt that the recent push towards digitalization will quickly influence the financial models.

Hassija and Srivastava (2020) found that one of the exciting and powerful technology in recent time is artificial intelligence and it going to become more necessary and universal in coming years and will going to make significant influence on the modern society. For large enterprises and start-ups, artificial intelligence is becoming very important. As per the research work done by the author, it is found that artificial intelligence has the capacity to add on about $\$ 1$ trillion to the Indian economy by year 2030. The adoption of artificial intelligence is still at beginning stage and to understand its potential lot of things needs to be done. Banking industry is able to offer and provide more personalized and efficient services to their customers by the help artificial intelligence and its application and different functions. By achieving 
such goals, banks have also been able to understand [perceptions of their customers as well as their expectations from banks.

Venkatesan and Sumathi (2019) concluded that the purpose of this work was to identify the perception of their customers with reference to the adoption of tools of artificial intelligence in banks. Implementation of artificial intelligence in the operation of business cannot hold clients but it will help is providing fine services to clients which will automatically make them stay back with the business. Artificial intelligence helps bank provide safe and trustworthy services to their clients and make them identify their mistake them might have made in the past.

\section{Objectives}

1. To know the importance of Artificial Intelligence in Financial sector.

2. To know the significance of Artificial Intelligence in the industry of finance.

\section{METHODOLOGY}

The present study is exploratory in nature. A survey method was used to collect the primary data from the respondents, for which a structured questionnaire was developed and used to validate the hypothesis of this study. A sample of 175 respondents has been considered. The sampling method was purposive sampling. Mean and t-test was applied to find out appropriate results of the study.

\section{Findings of the Study}

Table 1 shows that number of Male respondents are $62.29 \%$ and female respondents are $37.71 \%$, respondents. Respondents with the age group of 18 to 30 years are $23.43 \%$, those who are between the age group of 31 to 40 years are $18.86 \%$, those who were between 41 to 50 years were $45.71 \%$, and the respondents with 51 years $\&$ above are $12 \%$. With reference to the occupation of the respondents, banking sector professionals are $38.29 \%$, Insurance sector professionals are $29.71 \%$, and NBFC's professionals are $32 \%$.

Table1 Demographic profile of the respondents

\begin{tabular}{|l|c|c|}
\hline \multicolumn{1}{|c|}{ Variables } & $\begin{array}{c}\text { Number of } \\
\text { respondents }\end{array}$ & \%age \\
\hline \multicolumn{1}{|c|}{ Gender } & & \\
\hline Male & 109 & $62.29 \%$ \\
\hline Female & 66 & $37.71 \%$ \\
\hline Total & $\mathbf{1 7 5}$ & $\mathbf{1 0 0 \%}$ \\
\hline \multicolumn{1}{|c|}{ Age group } & 41 & $23.43 \%$ \\
\hline 18 to 30 years & 33 & $18.86 \%$ \\
\hline 31 to 40 years & 80 & $45.71 \%$ \\
\hline 41 to 50 years & 21 & $12 \%$ \\
\hline 51 and above & \multicolumn{2}{|c|}{} \\
\hline
\end{tabular}

\begin{tabular}{|l|c|c|}
\hline Total & $\mathbf{1 7 5}$ & $\mathbf{1 0 0 \%}$ \\
\hline $\begin{array}{c}\text { Occupation / } \\
\text { Sector }\end{array}$ & 67 & $38.29 \%$ \\
\hline $\begin{array}{l}\text { Banking sector } \\
\text { professionals }\end{array}$ & 52 & $29.71 \%$ \\
\hline $\begin{array}{l}\text { Insurance sector } \\
\text { professionals }\end{array}$ & 56 & $\mathbf{1 0 0 \%}$ \\
\hline NBFC's professionals & $\mathbf{1 7 5}$ & $32 \%$ \\
\hline Total & & \\
\hline
\end{tabular}

Table 2 Importance of Artificial Intelligence in Financial sector

\begin{tabular}{|c|c|c|}
\hline $\begin{array}{l}\text { Sr. } \\
\text { No. }\end{array}$ & Statements & $\begin{array}{l}\text { Mean } \\
\text { Score } \\
(.00)\end{array}$ \\
\hline 1. & $\begin{array}{l}\text { Artificial Intelligence helps in the } \\
\text { improvement of operational efficiency }\end{array}$ & 4.39 \\
\hline 2. & $\begin{array}{l}\text { Artificial Intelligence is important due to } \\
\text { rising competition in financial industry }\end{array}$ & 3.67 \\
\hline 3. & $\begin{array}{l}\text { Artificial Intelligence helps in the } \\
\text { introduction of self-service in banks }\end{array}$ & 3.70 \\
\hline 4. & $\begin{array}{l}\text { As customer demands for customized } \\
\text { services, adoption of artificial Intelligence is } \\
\text { important }\end{array}$ & 4.19 \\
\hline 5. & $\begin{array}{l}\text { Artificial Intelligence helps in effective } \\
\text { decision making }\end{array}$ & 4.38 \\
\hline 6. & $\begin{array}{l}\text { Artificial Intelligence helps in the reduction } \\
\text { of frauds and security threats }\end{array}$ & 3.65 \\
\hline 7. & $\begin{array}{l}\text { Artificial Intelligence helps in improving the } \\
\text { productivity of the employees }\end{array}$ & 4.10 \\
\hline 8. & $\begin{array}{l}\text { It helps in managing large volume of data at } \\
\text { high speed }\end{array}$ & 3.99 \\
\hline 9. & $\begin{array}{l}\text { Adoption of Artificial Intelligence boost } \\
\text { human work through software applications }\end{array}$ & 4.41 \\
\hline 10. & $\begin{array}{l}\text { It helps focusing on profitability and } \\
\text { Compliance }\end{array}$ & 4.16 \\
\hline
\end{tabular}

Table 2 shows the Mean value for the statements with reference to the "Importance and value of Artificial Intelligence in Financial sector." With reference to the first statement "Artificial Intelligence helps in the improvement of operational efficiency" has recorded the mean value of 4.39, next statement "Artificial Intelligence is important due to rising competition in financial industry" the mean value is 3.67 . Third statement is "Artificial Intelligence helps in the introduction of self-service in banks" the mean value for this statement is 3.70; another statement is "As customer demands for customized services, adoption of artificial Intelligence is important" the mean value for this statement is noted as 4.19. Fifth statement is "Artificial Intelligence helps in effective decision making" 4.38; next statement of the topic is "Artificial Intelligence helps in the 
reduction of frauds and security threats" the mean value is recorded as 3.65 . Seventh statement is "Artificial Intelligence helps in improving the productivity of the employees" the mean value is 4.10; statement "It helps in managing large volume of data at high speed" has the mean value of 3.99. The mean value is 4.41 for statement "Adoption of Artificial Intelligence boost human work through software applications" and the last statement is "It helps focusing on profitability and Compliance" the mean value is noted as 4.16.

\section{Table 3 Importance of Artificial Intelligence in Financial sector}

\begin{tabular}{|c|c|c|c|c|}
\hline $\begin{array}{l}\text { Sr. } \\
\text { No. }\end{array}$ & Statements & $\begin{array}{l}\text { Mean } \\
\text { Score }\end{array}$ & $\begin{array}{c}\mathbf{t} \\
\text { Value }\end{array}$ & Sig \\
\hline 1. & $\begin{array}{l}\text { Artificial Intelligence helps } \\
\text { in the improvement of } \\
\text { operational efficiency }\end{array}$ & 4.39 & 14.252 & 0.000 \\
\hline 2. & $\begin{array}{l}\text { Artificial Intelligence is } \\
\text { important due to rising } \\
\text { competition in financial } \\
\text { industry }\end{array}$ & 3.67 & 3.795 & 0.000 \\
\hline 3. & $\begin{array}{l}\text { Artificial Intelligence helps } \\
\text { in the introduction of } \\
\text { self-service in banks }\end{array}$ & 3.70 & 2.732 & 0.003 \\
\hline 4. & $\begin{array}{l}\text { As customer demands for } \\
\text { customized } \\
\text { adoption of arvices, } \\
\text { Intelligence is important }\end{array}$ & 4.19 & 9.722 & 0.000 \\
\hline 5. & $\begin{array}{l}\text { Artificial Intelligence helps } \\
\text { in effective decision making }\end{array}$ & 4.38 & 9.757 & 0.000 \\
\hline 6. & $\begin{array}{l}\text { Artificial Intelligence helps } \\
\text { in the reduction of frauds } \\
\text { and security threats }\end{array}$ & 3.65 & 2.010 & 0.023 \\
\hline 7. & $\begin{array}{l}\text { Artificial Intelligence } \\
\text { in improving } \\
\text { productivity of the } \\
\text { employees }\end{array}$ & 4.10 & 9.453 & 0.000 \\
\hline 8. & $\begin{array}{l}\text { It helps in managing large } \\
\text { volume of data at high speed }\end{array}$ & 3.99 & 7.538 & 0.000 \\
\hline 9. & $\begin{array}{l}\text { Adoption of Artificial } \\
\text { Intelligence boost human } \\
\text { work through software } \\
\text { applications }\end{array}$ & 4.41 & 12.250 & 0.000 \\
\hline 10. & $\begin{array}{l}\text { It helps focusing on } \\
\text { profitability and Compliance }\end{array}$ & 4.16 & 8.356 & 0.000 \\
\hline
\end{tabular}

Table 3 shows that all the above statements with reference to the Importance and value of Artificial Intelligence in Financial sector are found to be significant, as the t-value for all the statements are positive and significance value is less than 0.05.

\section{CONCLUSION}

As per the outcome of the study, in recent years Artificial intelligence has moved across a large front. Irrespective of the industry, artificial intelligence has provided lot of opportunities to financial institutions by bringing significant changes in their traditional method of working to modern one. There are different types of artificial intelligence applications and tools that are used by different organization in the everyday operations. It has grown up globally however the businesses in Asia/pacific are the most proactive in the implementation of artificial intelligence. There is no doubt that the future generation will be highly dependent on the tools of artificial intelligence. Digitalization will become the main stream. It is recommended that the financial sectors must adjust their procedures as per the techniques of artificial intelligence for effective transformation. Professionals of financial sectors must adopt this new technology with the changing environment of technology. "Mean" and "t-test" been applied to find out the motivation of students to study in Urdu and English Medium.

\section{REFERENCES}

[1] Patel, K. (2018). Artificial Intelligence in Finance, International Journal for Scientific Research \& Development, 4(4), 2787-2788.

[2] Patil, K. and Kulkarni, M. (2019). Artificial Intelligence in Financial Services: Customer Chatbot Advisor Adoption, International Journal of Innovative Technology and Exploring Engineering (IJITEE), 9(1), 4296-4303.

[3] Kumar, S.,Aishwaryalakshmi, S., and Akalya, A. (2020). Impact and Challenges of Artificial Intelligence in Banking, Journal of Information and Computational Science, 10(2), 1101-1109.

[4] Xie, M. (2019). Development of Artificial Intelligence and Effects on Financial System, Journal of Physics, doi:10.1088/1742-6596/1187/3/032084, 1-6.

[5] Meghani, K. (2020). Use of artificial intelligence and block chain in banking sector : a study of scheduled commercial banks in India, Indian journal of applied research, 10(8), $1-4$.

[6] Vedapradha, R. and Ravi, H. (2018). Application of artificial intelligence in Investment banks, Review of Economic and Business studies, 11(2), 131-136.

[7] Vijay, C. (2019). Artificial intelligence in Indian banking sector: challenges and opportunities, International Journal of Advanced Research, 7(5), 1581-1587.

[8] Jewandah, S. (2018). How Artificial Intelligence Is Changing The Banking Sector -A Case Study of top four Commercial Indian Banks, International Journal of Management, Technology and Engineering, 8(7), 525-530.

[9] Mhlanga, D. (2020). Industry 4.0 in Finance: The Impact of Artificial Intelligence (AI) on Digital Financial Inclusion, International Journal of Financial Studies, 8(45), 1-1-14.

[10] Kumar, N., Srivastava, J. and Bisht, H. (2019). Artificial Intelligence in Insurance Sector, Journal of the Gujarat Research Society, 21(7), 79-91.

[11] Burri, R., Burri, R., Bojja, R., and Buruga, S. (2019). Insurance Claim Analysis Using Machine Learning Algorithms, International Journal of Innovative Technology and Exploring Engineering, 8(6S4), 577-582.

[12] Alzaidi, A. (2018). Impact of Artificial Intelligence on Performance of Banking Industry in Middle East, IJCSNS International Journal of Computer Science and Network Security, 18(10), 140-148.

[13] Lakshminarayana, N. and Deepthi, B.R. (2019). Advent of Artificial Intelligence and its Impact on Top Leading Commercial Banks in India - Case Study, International 
Journal of Trend in Scientific Research and Development (IJTSRD), 3(4), 614-616.

[14] Hassija, T. and Srivastava, P. (2020). Impact of Artificial Intelligence in customer satisfaction for Banking Industries, International Journal of Advanced Science, and Technology, 29(9s), 1947-1962.

[15] Venkatesan, S. and Sumathi, N. (2019). Technology Acceptance of Artificial Intelligence in Banking and its Impact on Banking Efficiency, International Journal of Innovative Technology and Exploring Engineering (IJITEE), 8(7C2), 371-374.

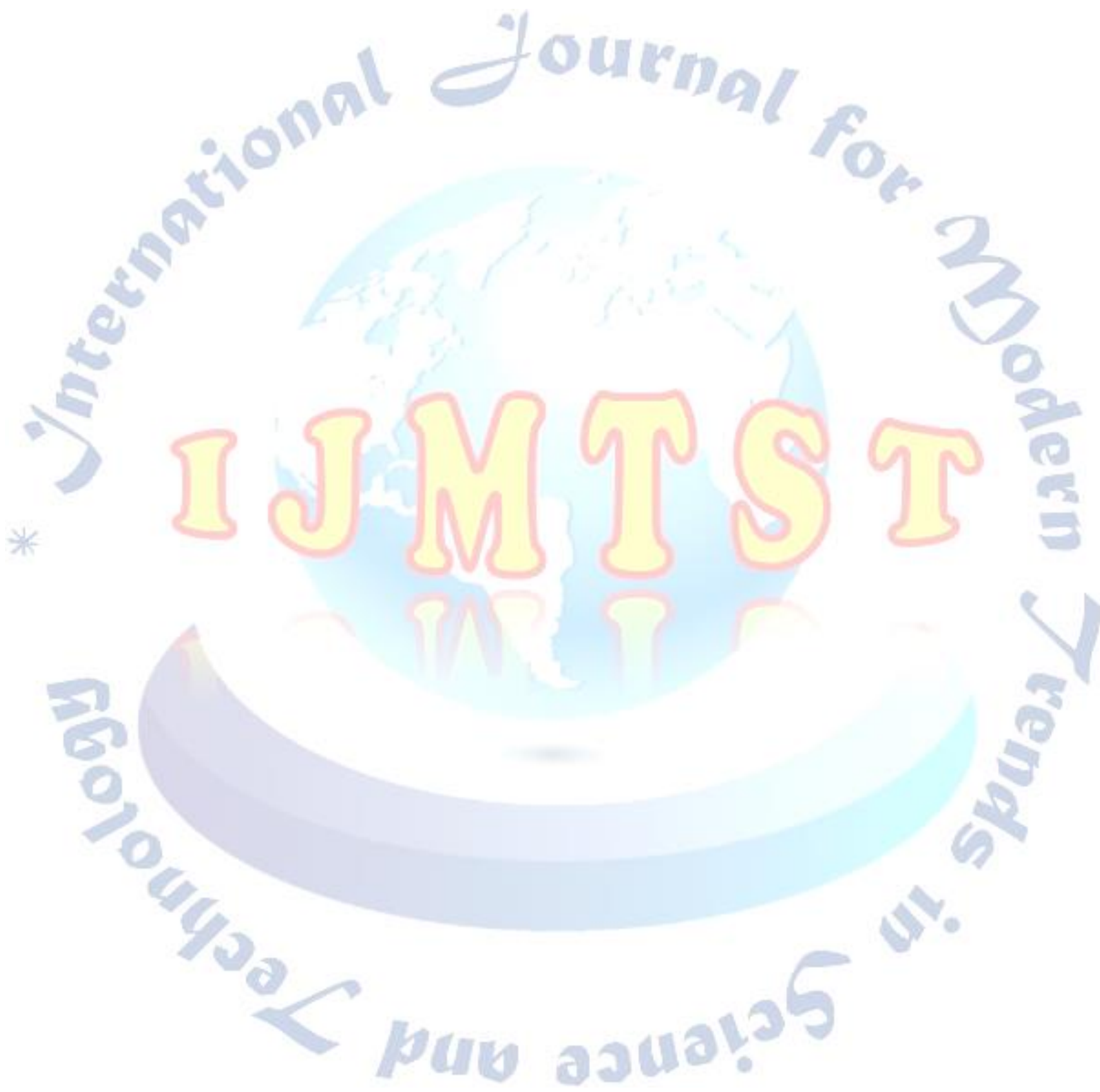

